\title{
Tax vs. Debt Management Under Entitlement Spending: a Multicountry Study
}

\author{
Floriana Cerniglia' • Enzo Dia² • Andrew Hughes Hallett ${ }^{3,4}$
}

Published online: 9 November 2018

(C) The Author(s) 2018

\begin{abstract}
In this paper we study the taxes vs. debt choice for public funding when spending is in large part predictable due to entitlement programs, but the necessary fiscal corrections may not be instantly and indefinitely elastic as usually assumed. We study fiscal behavior in a large sample of countries to determine what fiscal regimes have been used in practice, and what they reveal about the trade-off between raising taxes vs. issuing debt. Unsurprisingly, we find that fiscal discipline and the aims of fiscal rules have varied over the past 50 years. Discipline has generally weakened and there has been a greater tendency to use debt. But governments are no less forward looking than they were. Perhaps more surprising, the high debt countries were more disciplined than low debt economies — but with worse outcomes because of their poor starting positions and more persistent public spending. The low debt countries have exploited their stronger initial position to allow less discipline; a "resting on one's laurels" approach.
\end{abstract}

Keywords Sustainable public debt · Fiscal targets · Tax smoothing

JEL Classification E62 · H53 · H63 · I38

Andrew Hughes Hallett

ahughesh@gmu.edu

Floriana Cerniglia

floriana.cerniglia@unicatt.it

Enzo Dia

enzo.dia@unimib.it

1 Università Cattolica del Sacro Cuore, Milan, Italy

2 Università degli Studi di Milano-Bicocca, Milan, Italy

3 Kings College, University of London, London, UK

4 George Mason University, Fairfax, USA 


\section{Introduction}

The standard analysis of public debt management traditionally assumes that spending liabilities only enter into public debt calculations as current liabilities. But since the future path of expenditure is mostly predictable, we have to put the analysis of debt control and fiscal sustainability into an intertemporal framework if we are to account for persistence in entitlement spending or other liabilities if only because debt is a stock and taxes are a flow. Any costs induced by rising debt must be internalized by the government: both where financial stress is caused by anticipated risk premia or where policymakers are elected by voters who are averse to public debt.

In this paper we adopt the dynamic version of Barro's (1979) model developed by Cerniglia et al. (2016), where the government faces both convex costs in tax revenues and in debt. That means any cost induced by rising debt is internalized by the policy makers. ${ }^{1}$ We then recover the underlying parameter values for fiscal preferences, and the resulting implicit targets for taxes and the debt-to-GDP ratio as a function of the underlying structural parameters and market interest rates that governments have followed, under the assumption that governments can manage their liabilities by following this kind of inter-temporal framework.

Economists often believe that policy-makers are myopic and that the accumulation of public debt is the result of short-run political incentives rather than of a rational management of government liabilities. Here we take a different view and ask what we can infer about government's fiscal choices under the assumption that they have followed an intertemporal management of taxes and debt: Have they actually been myopic? Has their behaviour changed over time? What made the high debt countries different from low debt ones?

We estimate the model for a large sample of countries using panel data techniques, and we repeat the analysis for different time periods, to check if and how preferences have changed over time. We also distinguish the behaviour of the different groups of countries by treating them separately.

We find that governments do not discount future fiscal imbalances away, as is commonly supposed, but place some weight on maintaining reasonable fiscal balances in the future. Governments have therefore not been myopic; they have been weakly forward-looking about their potential fiscal problems. Governments have also been able to exploit an interesting trade-off between tax smoothing and debt management, implying that the more expensive is the use of debt, the more you want to use the cheaper alternative: tax increases or to encourage tax changes. Conversely, when smoothing taxes is costly, governments tend to use debt more. Governments have actively encouraged, or at least accommodated, loose tax policies that may deviate from their target paths because they have benefited from weak penalties on the use of debt. Hence they have encouraged tax smoothing in fiscal management. This trade-off between taxes and debt financing strengthens after 1994, with increased

\footnotetext{
${ }^{1}$ The formal structure extends the framework of Bohn (1990) to include the non-linearities in the cost of debt that capital markets impose as the fiscal space declines, as in Ghosh et al. (2013) and Checherita et al. (2014).
} 
preferences for using debt financing and a reluctance to use taxation. Thus preferences have been for tax aversion or tax smoothing but weakly accommodating for debt. This pattern gradually weakened over time since the 1980 s, especially pre-crisis (1990-2008), but became more tax averse and debt permissive in the crisis period. The last time discipline was seen in a conventional sense was before 1990, when governments were debt averse but were prepared to raise taxes for their spending or consolidation plans.

For low debt countries we find that policy preferences were the same as for the whole sample. That is to say, in low debt countries the use of taxes has been more encouraged, while, at the same time, the use of debt has been marginally more forgiving or permissive at the margin.

For the high debt countries we find that taxes have been used to smooth fiscal policies and consolidation in a more disciplined way in all periods, more so than in the low debt economies, and that debt has been more disciplined in all periods.

Section 2 presents a theoretical model for the optimal intertemporal choices of debt and taxation, together with the conditions for debt stability. Section 3 then illustrates an application of the model to the main OECD economies by means of panel data estimates. Section 4 reviews those results in terms of the fiscal policy regimes that have been in place over the years. Section 5 concludes.

\section{An Intertemporal Framework for Choosing Debt and Taxation}

In this section we derive an intertemporal framework for governments that internalize the costs that are expected to arise from raising revenues and issuing taxes, under the assumption that a substantial share of expenditure consists of entitlement spending that may be treated as an exogenous stochastic process and hence largely predictable. Accordingly, we assume that public expenditure $G_{t}$ is composed of entitlement spending $E_{t}$ and discretionary spending $V_{t}$, where entitlement spending is driven by an exogenous process such as (10) below:

$$
G_{t}=E_{t}+V_{t} \text {. }
$$

The primary deficit $D_{t}$ is the difference between expenditure $G_{t}$ and tax revenues $T_{t}$, where expenditure is total general government expenditure net of interest payments, while taxes include all general government revenues: ${ }^{2}$

$$
D_{t}=G_{t}-T_{t}=-S_{t} .
$$

By substituting deficit from Eq. 2 into the law of motion of debt:

$$
B_{t+1}=B_{t}+\left(r_{t}-\rho_{t}\right) B_{t}-S_{t},
$$

we get, in each period, taxes equal to:

$$
T_{t}=G_{t}-B_{t}+\left(1+r_{t-1}-\rho_{t-1}\right) B_{t-1} .
$$

\footnotetext{
${ }^{2}$ All variables are measured as ratios to GDP.
} 
To keep the model tractable we assume that discretionary spending is financed with tax revenues (but borrowing is allowed to cover entitlement spending):

$$
V_{t}=\tau T_{t} .
$$

and thus

$$
T_{t}=\psi\left[E_{t}-B_{t}+\left(1+r_{t-1}-\rho_{t-1}\right) B_{t-1}\right],
$$

where $\frac{1}{1-\tau}=\psi$, and $0<\tau<1$. Since discretionary spending is smaller than entitlement spending, this assumption does not imply any restrictions. The choice of funding by taxation or debt is now made for a given or predicted composition of discretionary and entitlement spending.

Although Eq. 6 is standard, this formulation highlights that, as long as the costs imposed by raising taxes are not linear, any convex cost on $T_{t}$ generates an adjustment cost on the stock of debt. ${ }^{3}$ Together, these costs impose a ceiling on debt. Equation 6 can in fact be rewritten as

$$
T_{t}=\psi\left[E_{t}-\Delta B_{t}+\left(r_{t-1}-\rho_{t-1}\right) B_{t-1}\right] .
$$

As a consequence, whenever (non-linear) cost functions for taxes apply, the problem becomes dynamic, even without assuming non-linear cost functions for the stock of debt or its adjustment. Our modelling strategy is therefore different from the standard model that analyzes the stock public debt as a sequence of period by period independent budget constraints, without recognizing the intertemporal constraints. In our approach, the objective function of policymakers is to provide the chosen expenditures while minimizing taxes and interest costs: ${ }^{4}$

$$
G O F=E_{t}+\zeta V_{t}+\frac{\delta}{2}\left(V_{t}\right)^{2}-v T_{t}-\frac{\varphi}{2}\left(T_{t}\right)^{2}-\frac{\beta}{2}\left(B_{t}\right)^{2}-r_{t} B_{t}
$$

Hence entitlement spending generates linear benefits, which we normalize to one, while discretionary spending generates linear and convex benefits whose importance is defined by the $\zeta$ and $\delta$ parameters. Similarly, $v$ and $\varphi$ define linear and nonlinear cost parameters associated with tax revenues. They include both resource costs induced by distortionary taxation, and political economy restrictions on government behavior reflecting the voters' aversion to taxes. Finally, the servicing of debt imposes a standard interest cost $r_{t}$. But the government needs to internalize any non-linear costs $\beta$ caused by non-linearly increasing risk premia in the interest payments, or by the voters' aversion to public debt. Defining $\gamma=\nu-\zeta \tau$ and $\alpha=\varphi-\delta \tau^{2}$, where the term in $\alpha$ represents the non-linear cost of taxes net of benefits obtained from discretionary spending, and $\gamma$ measures the linear cost of taxes net of benefits from

\footnotetext{
${ }^{3}$ The convexity assumption of Bohn (1990) is supported by the empirical results of Agell (1996) and Agell et al. (1996) suggesting that the distortionary effect of taxation are small for low levels of taxation, but they grow rapidly as taxes increase. These issues are extensively discussed by Leeper and Walker (2011). For a discussion on the relationship between different categories of expenditures and fiscal consolidation strategies see also Prota and Grisorio (2018).

${ }^{4}$ This objective function is fully dynamic, since it includes both flows and stocks.
} 
discretionary spending, we rewrite the policymakers' objective as

$$
G O F=E_{t}-\gamma T_{t}-\frac{\alpha}{2}\left(T_{t}\right)^{2}-\frac{\beta}{2}\left(B_{t}\right)^{2}-r_{t} B_{t},
$$

Policymakers maximize (9), subject to equation (6) and equations that define the stochastic process of expenditure, interest rates, and GDP growth. For example, we can model the latter as exogenous AR(1) processes:

$$
\begin{gathered}
E_{t+1}=E_{t}+\alpha+\eta_{t+1}, \\
r_{t+1}=r_{t}+\beta+\epsilon_{t+1}, \\
\rho_{t+1}=\rho_{t}+\gamma+\theta_{t+1},
\end{gathered}
$$

where $\eta_{t+1}, \epsilon_{t+1}$, and $\theta_{t+1}$, are i.i.d. random shocks with zero mean and constant variances. Defining $d$ as the discount factor, the Lagrangian form of the problem is:

$$
\begin{aligned}
\Lambda= & d^{t}\left\{E_{t}-\gamma T_{t}-\frac{\alpha}{2}\left(T_{t}\right)^{2}-\frac{\beta}{2}\left(B_{t}\right)^{2}-r_{t} B_{t}\right. \\
& \left.+\mu_{t}\left[T_{t}-\psi E_{t}+\psi B_{t}-\psi\left(1+r_{t-1}-\rho_{t-1}\right) B_{t-1}\right]\right\} .
\end{aligned}
$$

The first order conditions of the problem are the following:

$$
\begin{gathered}
\frac{\partial \Lambda}{\partial T_{t}}=-\gamma-\alpha T_{t}+\mu_{t}=0 . \\
\frac{\partial \Lambda}{\partial B_{t}}=-\beta B_{t}-r_{t}+\psi \mu_{t}-d \psi\left(1+r_{t}-\rho_{t}\right) \mu_{t+1}=0 . \\
\mu_{t}=\gamma+\alpha T_{t} .
\end{gathered}
$$

Given $v=1-\tau$, from the first order conditions we get a law of motion for tax revenues:

$$
\left(1+r_{t}-\rho_{t}\right) T_{t+1}=\frac{1}{d} T_{t}-\frac{1}{d \alpha}\left[-\gamma(1-d)+(v+d \gamma) r_{t}-d \gamma \rho_{t}+\frac{\beta}{1-\tau} B_{t}\right],
$$

and a law of motion for government debt that shows how expenditure shocks are absorbed by new debt issuance:

$$
\begin{aligned}
\Delta B_{t+1}= & \left(1+r_{t}-\rho_{t}\right) G_{t+1}-\frac{1}{d} G_{t}-\left(r_{t}-\rho_{t}\right) B_{t+1}+\left[\left(r_{t}-\rho_{t}\right)^{2}\right. \\
& \left.+2\left(r_{t}-\rho_{t}\right)\right] B_{t}+\frac{1}{d} B_{t}-\frac{1}{d}\left(1+r_{t-1}-\rho_{t-1}\right) B_{t-1} \\
& +\frac{1}{d \alpha}\left[-\gamma(1-d)+(v+d \gamma) r_{t}-d \gamma \rho_{t}+\frac{\beta}{1-\tau} B_{t}\right] .
\end{aligned}
$$




\subsection{The Stability of Debt}

Equation 18 allows us to look at fiscal stability directly. Using Eq. 2, the debt dynamics are: ${ }^{5}$

$$
\begin{aligned}
B_{t+1}-G_{t+1}-\left(r_{t}-\rho_{t}\right)\left[\left(1+r_{t-1}-\rho_{t-1}\right) B_{t-1}\right]= & a_{0}+a_{2} T_{t}+\left(1+a_{6}\right) B_{t}+a_{7} r_{t} \\
& -a_{8} \rho_{t}+\left(r_{t}-\rho_{t}\right)\left[\Delta T_{t+1}+G_{t}\right]+\epsilon_{t}
\end{aligned}
$$

where

$$
a_{0}=\frac{\gamma(1-d)}{d \alpha}, \quad a_{2}=-\frac{1}{d}, \quad a_{6}=\frac{\beta}{d \alpha(1-\tau)}, \quad a_{7}=\frac{v+d \gamma}{d \alpha}, \quad a_{8}=-\frac{\gamma}{\alpha} .
$$

Debt will be stable if and only if the fiscal system

$$
\begin{aligned}
{\left[\begin{array}{l}
B_{t+1} \\
B_{t}
\end{array}\right]=} & {\left[\begin{array}{ll}
1+a_{6} & c \\
1 & 0
\end{array}\right]\left[\begin{array}{l}
B_{t} \\
B_{t-1}
\end{array}\right]+a_{0}+a_{2} T_{t}+a_{7} r_{t}-a_{8} \rho_{t}+G_{t+1} } \\
& +\left(r_{t}-\rho_{t}\right)\left[\Delta T_{t+1}+G_{t}\right]+\epsilon_{t},
\end{aligned}
$$

has roots inside the unit circle, where $c=\left(r_{t}-\rho_{t}\right)\left(1+r_{t-1}-\rho_{t-1}\right)$ and where $T_{t}$ are choice variables at each $t$. The stability of the fiscal system is controlled by the roots of Eq. 20, $\lambda_{1,2}$, obtained by solving

$$
\lambda^{2}-\left(a_{6}+1\right) \lambda-c=0,
$$

where $a_{6}>0$ by definition given the policy cost function (8). Hence,

$$
\lambda_{1,2}=\frac{1}{2}\left\{a_{6} \pm \sqrt{\left(a_{6}+1\right)^{2}+4 c}\right\}=\frac{a_{6}+1}{2} \pm \sqrt{\left(\frac{a_{6}+1}{2}\right)^{2}+c} .
$$

Note that $c$ will have the sign of $r_{t}-\rho_{t}$ in all but quite exceptional circumstances since $r_{t-1}-\rho_{t-1}$ will measure only a few percentage points and therefore be a good deal less than unity. That means there are just two cases to consider:

1. $r_{t}-\rho_{t}>0$, so $c>0$. In this case, the dynamics implied by Eqs. 18 and 20 are always unstable since Eq. 22 implies $\lambda_{1}>1+a_{6}>1$. So at least one root greater than unity implies instability and unsustainable fiscal policies.

2. $r_{t}-\rho_{t}<0$, so $c<0$. The positive root from Eq. 22, $\lambda_{1}$ will lie in the unit circle if

$$
\sqrt{\left(\frac{a_{6}+1}{2}\right)^{2}+c}<1-\frac{a_{6}+1}{2} \quad \text { that is, if } c<-a_{6} \text {. }
$$

\footnotetext{
${ }^{5}$ Notice that the distinction sometimes drawn between global stability and saddle path stability does not apply here: a first order lead-lag (forward, backwards) dynamic system is equal to a renormalized second order (backwards) difference equation provided the coefficients on the lead term are invertible [Fisher and Hughes Hallett (1988)]. This is the case in Eq. 18.
} 
In addition, we need to have the right hand side positive: $1-\frac{a_{6}+1}{2}>0$. This requires $a_{6}<1$, or $\beta<d \alpha$, given the definition of $a_{6}$. This is a necessary condition; the rest of the inequality, $c<-a_{6}$, is sufficient. This restriction implies that with weak or no discounting $(d \simeq 1)$ policymakers have to worry more about taxes than debt. If governments apply a negative discount rate, and thus $d>1$, debt stability becomes much easier to achieve, and the penalty cost on using taxes declines proportionally for a given $\beta$. Intuitively, the more governments discount the future, the more they can tolerate debt instability, since the higher future taxes have a small weight in the decision process. Conversely, when they apply negative discount rates, they need to impose large weights on tax costs, but the resulting debt is always stable and involves smaller future taxes.

\section{Comments:}

1. It is worth noting that stability in this type of model involves roots that are based on time-varying parameters.

2. In the stable case, $r_{t}-\rho_{t}<0$, the necessary condition to have positive debt in steady state, which is $\frac{\beta}{\alpha(1-\tau)}<\kappa[1-d(1+\kappa)]$, can be satisfied even if $\frac{\beta}{\alpha(1-\tau)}<0$. The model can therefore have a stable equilibrium even if the convex cost of debt is zero or less; and debt will have a natural ceiling, if there are costs to using the tax instrument.

\section{An Application to Developed and Developing Economies}

\subsection{Data}

The fiscal data come from the IMF Public Finances in Modern History Database, produced by Mauro et al. (2015). All the data correspond to annual observations and all variables are expressed as ratios to GDP, data on public debt measure the current evaluation of the book value of debt. Output (GDP) growth rates are obtained from the same source.

The data base provides a very long time series for a few countries; the data run until 2011, but the initial years of data differ among countries. Since we want to analyze a coherent set of countries over time, we chose to have a balanced panel. Hence we choose 1960 as a starting point. The sample includes 22 advanced economies: United States, United Kingdom, Italy, Canada, Australia, Portugal, Switzerland, Ireland, Spain, France, Norway, Sweden, Japan, New Zealand, Austria, Finland, Greece, Belgium, Netherlands, Germany, Iceland, Denmark.

To allow for the possibility that policy and behaviour with respect to debt management, taxation, public spending and entitlement spending have shifted over time, we split the sample into separate periods to provide individual estimates of our model for the pre-Maastricht (or cold war) period 1960-1989; the pre-financial crisis era (1990-2008); the crisis vs recovery eras (1994-2008, 1994-2011) respectively, and various other permutations. We also separate low-debt from high-debt countries. 


\subsection{Estimating Equations and Extracting the Underlying Fiscal Preference Parameters}

In order to estimate the revealed preferences for controlling tax revenues and debt management in the consolidated objective function (9) that determines the tax and debt choices given a choice for the share of entitlement or discretionary spending in total public spending, we start from Eq. 17. The estimating equation would then be

$$
\left(1+r_{t}-\rho_{t}\right) T_{t+1}=b_{0}+b_{1} T_{t}+b_{2} r_{t}+b_{3} \rho_{t}+b_{4} B_{t},
$$

where $b_{0}=-\frac{\gamma(1-d)}{d \alpha} \quad b_{1}=\frac{1}{d} ; \quad b_{2}=-\frac{v+d \gamma}{d \alpha} \quad b_{3}=\frac{\gamma}{\alpha} \quad$ and $b_{4}=-\frac{\beta}{d \alpha(1-\tau)}$. We can then extract the preference parameters as follows: ${ }^{6}$

$$
d=\frac{1}{b_{1}} \quad \alpha=\frac{-v}{\left(b_{2}+b_{3}\right) d} \quad \gamma=b_{3} \alpha \quad \text { and } \quad \beta=-b_{4} d \alpha(1-\tau) .
$$

where $v=(1-\tau)$ and $\tau$ is the chosen or historical share of discretionary spending from available revenues. ${ }^{7}$

Notice that this approach allows $\tau=0$ as a special case. Hence this framework can also be used when control over revenues or debt derived from entitlement spending is the only issue of concern, or when the entitlement or social security budget is separated from the rest of public spending (as it is in the US and many EU countries, but not the UK).

Notice also that Eq. 24 implies that the discount factor, $d$, is independent of the choice of $\tau$. But $\alpha$, the penalty for not keeping to the targets for taxation, will rise or fall as $\tau$ becomes larger depending on the sign of the $b_{2}+b_{3}$ term, as do $\beta$ and $\gamma$ also. In other words, we cannot say a priori whether tax or debt discipline will get stronger as a larger proportion of discretionary spending is chosen from a given revenue stream; or if entitlement spending becomes more important as a component of public spending.

\subsection{Estimation Techniques}

We run fixed effects regressions with one lag in the autocorrelation structure of the error term. However, panel data estimation raises a potential conflict between communality in the behaviour across countries or time periods. To achieve useful results, we need sufficient communality in either dimension("poolability"). We can achieve that by using time or country fixed effects in the estimating equation's constant term and by subdividing the sample into different periods or country groups (high debt vs.

\footnotetext{
${ }^{6} \mathrm{We}$ do not use $b_{0}$ because, in practice, to satisfy the "poolability" criterion for panel data requires estimation with country specific effects.

${ }^{7}$ We choose the latter option: $\tau=0.3$. The countries of our sample all belong to the OECD, where discretionary spending is about $1 / 3$ of total government spending on average. This is relatively large compared to the estimated residuals of the auto-regressive models used to measure the share of expenditures that are not predetermined. However, it is small compared to what is assumed in econometric models that treat government spending as exogenous. See Coricelli and Fiorito (2013).
} 
low debt economies). But that comes at the cost of smaller samples. Since the estimating Eq. 24 is $\operatorname{AR}(1)$, the estimated $b_{1}$ coefficient will be subject to small sample bias. Consequently, the results that follow, correct for that bias using the formula due to White (1961) and Malinvaud (1970):

$$
b_{1}=E\left(\widehat{b_{1}}\right) /(1-2 / T)
$$

where $\widehat{b_{1}}$ is the raw panel data estimate.

Before estimating the model we address the issue of the presence of crosssectional dependence in our data set. Since we are analysing the behaviour of fiscal variables in economies with strong economic ties, it is likely that the countries in our sample were affected by common shocks during this time period and that can cause cross-sectional correlation in the residuals (Chudik and Pesaran 2013). The countries in our sample compete for the same market when issuing debt instruments; they are trading partners and as such face similar business, fiscal, and financial cycles. We test for cross-sectional dependence: the hypothesis of cross-sectional independence is strongly rejected in all cases, both for the entire sample and for the subsamples. Thus, to address the cross-sectional dependence in our panel, we use Driscoll-Kraay standard errors in our analysis.

\subsection{Results for All Countries, Tables 1-3 :}

In this section we recover the underlying parameters from the the regression results. Tables 1-3 display the results for the entire sample and for the samples of low debt and high debt countries respectively. The results of the regressions used to extract the parameters are displayed in Appendix.

\subsubsection{Results for All Countries in Detail}

1. The discount factor, $d$, is greater than one in all periods as required for fiscal stability. It varies from 1.057 over the whole period 1960-2011, to 1.03-1.05 pre-crisis, and a little over 1.2 in the periods post 1990 (Table 1). Hence governments have been consistently if mildly forward-looking, and became more so in the bad times after 1990 (the dot-com and great financial crises). They do

Table 1 Recovering the underlying parameters, from Eq. 24 with $v=0.7$, all countries

\begin{tabular}{lllllll}
\hline & $1960-2011$ & $1960-1989$ & $1960-2008$ & $1990-2008$ & $1994-2008$ & $1994-2011$ \\
\hline$d$ & 1.057 & 1.037 & 1.054 & 1.209 & 1.256 & 1.235 \\
$\alpha$ & -4.14 & -2.50 & -3.69 & -57.89 & -13.93 & -5.67 \\
$\gamma$ & 1.41 & 0.73 & 1.22 & 26.05 & 5.29 & 2.09 \\
$\beta$ & -0.00 & -0.022 & -0.019 & 0.539 & 0.196 & 0.044 \\
\hline
\end{tabular}

Notes: all estimates, with the exception of those for $\beta$, are constructed from coefficients that are significant at the 1\% level or stronger. For $\beta$ the same is true for 1994-2011 and 1994-2008, but otherwise they are constructed from estimates that are insignificant at the $10 \%$ level. 
Table 2 Recovering the underlying parameters, from Eq. 24 with $v=0.7$, low debt countries

\begin{tabular}{lllllll}
\hline & $1960-2011$ & $1960-1989$ & $1960-2008$ & $1990-2008$ & $1994-2008$ & $1994-2011$ \\
\hline$d$ & 1.068 & 1.037 & 1.054 & 1.296 & 1.376 & 1.347 \\
$\alpha$ & -4.37 & -2.50 & -4.74 & 2.57 & 12.72 & -2.73 \\
$\gamma$ & 1.75 & 0.80 & 1.85 & -1.44 & -5.47 & 1.15 \\
$\beta$ & 0.026 & -0.022 & 0.007 & -0.072 & -0.392 & 0.028 \\
\hline
\end{tabular}

Notes: all estimates, with the exception of those for $\beta$, are constructed from coefficients that are significant at the 1\% level or stronger. For $\beta$ the same is true for 1990-2008 while those for 1994-2008 are significant at the $5 \%$ level, but otherwise they are constructed from estimates that are insignificant at the $10 \%$ level.

not discount future fiscal imbalances away, as is commonly supposed, but place some weight on maintaining reasonable fiscal balances (or at least, preventing them from passing out of control). Nor is this just an artifact of the "all countries together" case, where countries are more disciplined about future average debt compared to those less disciplined about the future. Very similar results are also obtained for the low debt and high debt countries separately (Tables 2 and 3). So, this result is robust.

The implication is that governments have not been myopic as is usually argued; they have been weakly forward-looking about their potential fiscal problems. If this is true, then we need a new set of rules to test for fiscal sustainability that take into account the inter-temporal nature of fiscal decisions. That is what this paper provides. There are however some important variations. Governments in the low debt countries became more concerned to use taxes to stabilise their (at that point) healthy fiscal balances, and less concerned to control debt per se - in fact they were prepared to let it go in the period following 1990 (Tables 2 and 3; notice the sign changes). However there was a partial reversal in this approach as the financial crisis increased in severity in 2008-2011. This is a numerically strong result for the low debt countries, but unfortunately is not reproduced in the high debt economies.

2. Next, there is an interesting trade-off between debt control $(\beta)$ and tax aversion $(\alpha)$. See the sign pattern in Tables 2 and 3: the more you penalize the use of debt,

Table 3 Recovering the underlying parameters, from Eq. 24 with $v=0.7$, high debt countries

\begin{tabular}{lllllll}
\hline & $1960-2011$ & $1960-1989$ & $1960-2008$ & $1990-2008$ & $1994-2008$ & $1994-2011$ \\
\hline$d$ & 1.068 & 1.098 & 1.078 & 1.105 & 1.171 & 1.154 \\
$\alpha$ & -3.45 & -1.77 & -2.82 & -4.87 & -7.47 & -6.74 \\
$\gamma$ & 1.07 & 0.48 & 0.79 & 1.66 & 2.54 & 2.36 \\
$\beta$ & 0.003 & 0.027 & 0.004 & 0.026 & 0.067 & 0.044 \\
\hline
\end{tabular}

Notes: all estimates, with the exception of those for $\beta$, are constructed from coefficients that are significant at the 1\% level or stronger. For $\beta$ the estimates for 1994-2008 and 1994-2011 are significant at the 5\% level, but otherwise they are constructed from estimates that are insignificant at the $10 \%$ level. 
the more you accommodate tax increases or encourage tax changes (and vice versa) especially in the crisis periods post 1990 . This might be characterized as the usual "tax now" vs. "tax later" trade off. In other words, there is an emerging trade-off between tax smoothing and debt management; more weight on one produces implicit restrictions, and hence higher penalties, on the other. This is also seen in the somewhat weaker penalties in the high debt countries. Hence, the trade-off remains in the high and low debt countries, although it has been weaker (and hence easier to exploit) in the high debt countries. Nevertheless, tax smoothing has become overall more permissive since 1994.

3. The sign pattern noted above shows that governments actively encouraged, or at least accommodated, loose tax policies may deviate from the target paths set for them (defined in Section 3.6 below), compensated by weak penalties against the use of debt and hence tax smoothing. ${ }^{8}$ This is true on average as well as in high debt countries (Section 3.5.2). The only exception is the low debt countries where the pattern is reversed post 1990 and in the financial crisis, when debt or tax smoothing policies were encouraged around the target paths defined in Table 5. But in 1990, the penalties on lax or unfocused tax policies are replaced by penalties that permit debt financing but penalise the lack of effort to raise taxes.

The story is very different in high debt countries: there the use of the tax instrument was increasingly accommodated whether for expansion or consolidation (the latter after 1990, the former pre-1990: see Table 6), while debt was mildly discouraged.

4. There is something different about fiscal preferences from the 1960s to 1980s. That period was somewhat less forward looking (smaller discount factors) but perhaps more disciplined. The trade-off between taxes and debt financing then changes after 1990, with high debt countries continuing to penalise the use of debt financing, but encourage tax smoothing, while low debt countries switch (more aggressively) to interventions to raise taxes, but temporarily encourage debt financing.

5. Thus, preferences are mostly for tax aversion or tax smoothing and weakly accommodating for debt. This pattern gradually weakened over time and it eventually reversed pre-crisis (1990-2008). The last time discipline was seen in a conventional sense was before 1990, when governments were debt averse but were prepared to raise taxes for their spending or consolidation plans (see the rather stable tax targets as a share of GDP $-\gamma / \alpha$ in Section 3.6) as one might expect from disciplined policymakers

6. The linear cost term on taxes is consistently strong and tightens perceptively relative to the quadratic penalties after 1990 (except in the tax discipline interval for low debt countries). The implicit target for tax revenues, $-\gamma / \alpha$, is consistently in the range $29 \%$ to $34 \%$ in the crisis. Interestingly the target tax rate rises to $61 \%$

\footnotetext{
${ }^{8}$ The large negative values of alpha 1990-2008 in Table 1 comes from $b_{2}+b_{3}$ in $\alpha$ below (24) being insignificantly different from zero. These alpha values therefore reflect a statistical shortcoming, not a change in behavior. They are discounted in what follows.
} 
in the early part of the crisis, but then falls back to $54 \%$ if the later crisis period is included. This is consistent with making taxes more flexible and higher as the fiscal implications of the crisis appeared (recall the penalties in Table 2), but then easing back again as the counter-productive outcomes of austerity became clear. The high debt economies, by contrast show continued tax smoothing throughout, albeit with lower tax ratio targets than the average. Meanwhile, the implicit targets for the debt ratio are variable, tightening to provide a cushion of net assets in good times in high debt countries, but loosening as needed in bad times.

\subsection{Low vs High Debt Countries in Detail}

For the purposes of this exercise, we define the low debt countries to be those whose debt-to-GDP ratio has never risen above $90 \%$ in our sample period: that is Denmark, Germany, Netherlands, Finland, Sweden, Switzerland, Austria, Norway, Spain, France, United Kingdom, New Zealand and Australia. Thus, historically good performers (the US and Ireland) are not in this group — but mostly because their fiscally accommodating record in the financial crisis and recovery periods kept them out. They, and the remainder of our sample economies, form the high debt group of countries.

\subsubsection{The Low Debt Countries, Table 2}

1. Their estimates are more stable over time ( $d$ excepted) compared to the average. But interestingly the fiscal preference parameters, and hence the implicit target values, are more consistent and less interventionist in the high debt economies.

2. The $\gamma$ 's tend to be smaller than average, but then switch sign with $\alpha$ values in the crisis period, which implies more ambitious targets in terms of consolidating the fiscal position. The $\alpha$ 's too are smaller/less negative in low debt countries, leading to greater tax permissiveness pre-1990, but this reverses decisively after 1990. Meanwhile the $\beta$ 's are more often negative in the low debt countries after 1990 allowing greater debt accommodation.

3. Because the $\alpha$ 's are less negative and $\gamma$ 's smaller, most of the aversion to raising taxes (above higher targets for the tax share, Table 5) and the greater preference for debt accommodation (around higher targets for debt, as opposed to higher asset ratios as a future cushion) has come from the low debt countries_-although the tax aversion part of this is reversed in the period immediately before the financial crisis.

4. If the high debt countries show greater willingness to control debt or use taxes, we should conclude that market discipline works up to a point. We already saw some evidence of that on the tax side (Table 3).

5. The linear terms have been weakening relative to the quadratic loss terms. Targets have therefore become more restrictive while aimed at tax revenues; also for debt in the low interest rate era, but the penalties for missing those targets have dropped since 1990. Pious words, but little discipline - probably in order to avoid counterproductive austerity. 


\subsubsection{The high Debt Countries, Table 3}

1. Here the sign patterns remain broadly the same, but preference parameters are mostly more permissive with respect to tax after 1990, but more restrictive with debt, than in the low debt countries. More discipline, starting from a worse position with more persistent spending patterns therefore. ${ }^{9}$ The low debt countries are "resting on their laurels" (trading their stronger initial position for somewhat less discipline).

2. Tax restraints (penalties on using taxes) were weaker 1960-1990 - meaning that they became stronger for tax smoothing around relatively low tax targets, again to avoid counter-productive austerity results. However, the implicit targets are only mildly increasing (Table 6).

3. Debt is never accommodating here: in fact it is only weakly disciplined, becoming a little stronger after 1994. But the discipline, while present, is always weak which explains how these countries came to be high debt economies.

4. The preference parameters are all more stable than in Table 1, meaning more consistency in the way the policies are used.

5. Some changes to tax aversion: It was stronger in 1960-1989 but then weakened, with a preference for smoothing, thereafter. That meant little fiscal discipline even as the (largely unsuccessful) pressure to build up protective asset ratios weakened (Table 6).

\subsection{Implicit Target Values}

Given the apparent counterintuitive results of negative values for either $\alpha$ or $\beta$ (but never both), and the strong role for $\gamma$, it is important to give a more detailed and nuanced view of the different policy regimes implied by Tables 1 to 3 . The main question is: when do the costs of fiscal expansion rise with an increasing use of the policy instruments despite the negative values of $\alpha, \beta$ or $\gamma$ in each period? Objective function (9) implies increasing costs if

$$
\frac{\partial \operatorname{cost}(T)}{\partial T}=2 \alpha T_{t}+\gamma>0
$$

and

$$
\frac{\partial \cos t(B)}{\partial B}=2 \beta B_{t}+r_{t}>0 .
$$

The implicit targets automatically implied by the objective function GOF can thus be recovered. From Eq. 9:

$$
G O F=E_{t}-\gamma T_{t}-\frac{\alpha}{2} T_{t}^{2}-r_{t} B_{t}-\frac{\beta}{2} B_{t}^{2},
$$

\footnotetext{
${ }^{9}$ See Cerniglia et al. (2016).
} 
Table 4 Implicit target values, ratios for all countries

\begin{tabular}{llllllll}
\hline & & $1960-2011$ & $1960-1989$ & $1960-2008$ & $1990-2008$ & $1994-2008$ & $1994-2011$ \\
\hline Tax & $-\gamma / \alpha$ & 0.34 & 0.29 & 0.33 & 0.45 & 0.338 & 0.37 \\
Debt & $-r / \beta$ & 653.1 & 1.84 & 2.10 & -.074 & -0.204 & -0.907 \\
\hline
\end{tabular}

Notes: this table assumes a nominal interest rate of $4 \%$ is payable on historical and future debt, a $2 \%$ real rate would halve these debt ratio targets.

the apparent (that is explicit) target for tax revenues is zero. But by combining linear and quadratic tax revenue terms, we have:

$$
G O F=E_{t}-\frac{\alpha}{2}\left(T_{t}+\frac{\gamma}{\alpha}\right)^{2} \ldots
$$

Hence the implicit target value for taxes is $\frac{-\gamma}{\alpha}$. By the same token, the explicit target for the debt to GDP ratio is zero, but the implicit debt target is $\frac{-r}{\beta}$.

\section{Hence for taxes:}

1. Since $\gamma>0$ but $\alpha<0$ pretty much everywhere, this implies implicit targets for average tax revenues of about 30\%-38\% (the low debt counties after 1990 excepted), see Tables 4, 5 and 6, for the typical economy over 1960-2011. That is an entirely plausible range, the U.S. apart perhaps, since $T$ is measured as a share of GDP.

2. These targets vary rather little over time. They are around 28\% in 1960-1989; but higher and more restrictive later in the pre- and crisis periods (up to $45 \%$ on average, but 56\% in the low debt countries, in 1994-2011 and 35\% in the high debt economies).

3. That means taxes were broadly neutral until the early 1990s; policymakers were trying to keep taxes from changing too much, but at the same time they tried to consolidate by raising taxes during, and just after the crisis period. Thus austerity measures were already in place after 1990.

4. The high debt countries were more consistent in their intended tax policies, with implicit targets of $31 \%$ in 1960-2011, and varying between $27 \%$ to $35 \%$ in the

Table 5 Implicit target values, ratios for low debt countries

\begin{tabular}{llllllll}
\hline & & $1960-2011$ & $1960-1989$ & $1960-2008$ & $1990-2008$ & $1994-2008$ & $1994-2011$ \\
\hline Tax & $-\gamma / \alpha$ & 0.40 & 0.32 & 0.39 & 0.56 & 0.43 & 0.42 \\
Debt & $-r / \beta$ & -1.53 & 1.84 & 5.72 & 0.55 & 0.10 & -1.41 \\
\hline
\end{tabular}

Notes: this table assumes a nominal interest rate of $4 \%$ is payable on historical and future debt, a $2 \%$ real rate would halve these debt ratio targets. 
Table 6 Implicit target values, ratios for high debt countries

\begin{tabular}{llllllll}
\hline & & $1960-2011$ & $1960-1989$ & $1960-2008$ & $1990-2008$ & $1994-2008$ & $1994-2011$ \\
\hline Tax & $-\gamma / \alpha$ & 0.31 & 0.27 & 0.28 & 0.34 & 0.34 & 0.35 \\
Debt & $-r / \beta$ & -15.5 & -1.47 & -9.39 & -1.52 & -0.59 & -0.92 \\
\hline
\end{tabular}

Notes: this table assumes a nominal interest rate of $4 \%$ is payable on historical and future debt, a $2 \%$ real rate would halve these debt ratio targets.

periods between those dates. So they were clearly tax smoothing, but had maintained a more expansionary stance going into the 1990s and significantly more so during the crisis and recovery.

5. The low debt countries were more contractionary, especially after 1990. They may have been fairly neutral or only slightly contractionary before then, and during the crisis period. Not much sign of austerity there, except in the early 1990s. However, their tax plans were more active than in high debt countries.

6. But $\alpha<0$ and $\beta>0$ for much of the crisis and pre-crisis period. So, although there was clear consolidation intent here, policymakers gave themselves the freedom to deviate away from their implicit targets as needed. That is to say, other things equal, tax policies were intended to be permissive or expansionary in low debt countries, but contractionary in the high debt economies.

\section{For Debt Targets:}

1. The numerical values for $\beta$, and consequently the implicit debt targets, are obtained from estimates of a coefficient that are close to zero, but never close to statistical significance in the samples beginning in 1960. On the contrary the estimates are mostly significant afterwards. Hence, although we report all the values, we do not comment on the results for the old sample, because they are unreliable.

2. Given $r, \beta \geq 0$, we have zero or negative targets for the debt ratio in most years, but turning to positive for on average after 1990, and in the high debt counties generally. Negative target values imply the policymakers were aiming at asset to GDP ratios, perhaps as a cushion against future adverse shocks, but only weakly so (and, as it turned out, unsuccessfully), given the small numerical values for $\beta$.

3. Suppose historical rates of $4 \%$ for actual (nominal) interest payments. The implicit targets were then set as debt ratios of 55\% or less in the low debt countries after 1990; 1.3\% in 1960-1989; but tightening to imply an asset ratio target in 1994. Again, this is contractionary relative to the historical debt figures, but not by much because the penalties for deviations were small.

4. For high debt countries, the implicit debt targets were for asset ratios of over $100 \%$ after the 1990s; but weakening to 50\% going into the crisis. Overall this is a more active strategy than in the low debt countries; but equally more contractionary than in the low debt countries. Its weakness was the small penalties on failure. 


\section{The Different Policy Regimes Operated at Different Times}

We can now define the four different policy regimes available as follows:

a) Forgiving or permissive: the first cost derivative, $\frac{\partial \cos t(T)}{\partial T}$ for the case of taxes, is positive; but the second, $\frac{\partial^{2} \operatorname{cost}(T)}{\partial T^{2}}$ in the case of taxes, is negative. ${ }^{10}$ In this case, the penalty on using the policy instrument is always increasing, but at a decreasing rate as the instrument is used more. This would be the case in debt forgiveness, for example.

b) Encouraging: the first and second cost derivatives are both negative. In this case the penalties placed on the use of the policy instrument decrease the more it is used.

c) Disciplined: the first and second derivatives are both positive. The cost of using the instrument rises the more the instrument is used, and increasingly so.

d) Accommodating: the first derivative is negative, but the second positive. In this case, a moderate use of the instrument is allowed without much penalty, or even encouraged. But a larger use is penalized, and increasingly so when the policy interventions go too far.

The parameter values obtained above therefore imply the following regimes:

i) For the whole sample. Member governments have been disciplined with respect to taxes (that is concerned to smooth taxes, or tax averse), including in 19601989 when the discipline to use taxes to fund their spending plans or stabilize their economies was strong; and in 1994-2014 when discipline was weaker but the implicit targets for taxes increased (inequality (25)). That is, policymakers felt free to increase taxes to finance their fiscal policies in the first period, and saw fewer increasing costs if they were to do so in later periods.

ii) By contrast, governments evidently encouraged the use of debt financing in the low interest and crisis periods, but less so in the 1960-1989 period when debt targets were more restrictive. This because inequality (26) fails, except in 19902011 where we would need $r>6 \%$ (interest rate payable on the stock of debt) to reverse that effect in a country with a $60 \%$ debt ratio. Since 1990 interest rates have been lower than that. This suggests governments have encouraged the use of debt after 1990, but had been merely permissive before then.

iii) For the low debt countries: The policy preferences in these countries are the same as those of the whole sample since the sign pattern in Tables 1 and 2 were similar. But because the $\alpha$ values are typically smaller in Table 2 than in Table 1, and switch sign after 1990, the use of taxes became more restrictive but less disciplined in low debt countries. That combination means that the use of debt has become more forgiving or permissive in low debt countries.

iv) For the high debt countries: The story for the high debt countries is the opposite, but simpler. It is easy to see that taxes have been used to fund the fiscal policies and some consolidation in a more disciplined way in all periods. Similarly, that debt has been more disciplined, but weakly aimed at creating asset ratios, in all periods.

The interesting thing about these results is that it appears that it is the low debt countries that had become used to allowing debt to fund their fiscal policies pre-crisis or

\footnotetext{
${ }^{10} \mathrm{~A}$ similar pattern can be ascribed to the first and second derivatives with respect to debt: (25).
} 
in the crisis, but have run disciplined or tax smoothing policies thereafter. That is the opposite of conventional wisdom, but their superior debt position allowed them to do so. By contrast, the high debt countries used taxes to fund their spending activities, but run a slightly more disciplined regime of debt control.

\section{Conclusion}

The procedures for managing public debt assumed and discussed in macroeconomic models involve feedback or multi-period open loop sequential control: Policy makers simply respond ex-post to realized outcomes period by period. Since government liabilities can either be flows (taxes), or stocks (debt), it is more efficient to manage debt and taxes in an intertemporal framework adopting a closed loop control approach, a process based on forecasting forward looking data plus a feedback adjustment for when new information becomes available.

In this paper we use a theoretical framework with these characteristics, where any cost induced by rising debt is internalized by policy makers, and derive the implicit targets for fiscal preferences implied by the model. We then assume that, in contrast with conventional wisdom, governments have managed their liabilities by following this more sophisticated inter-temporal framework. Having done that, we recover the underlying parameter values for fiscal preferences, and the implicit targets that governments have followed. We do so by estimating the model for a large sample of countries using panel data techniques.

We find that governments do not discount future fiscal imbalances away, as is commonly supposed, but place some weight on maintaining reasonable fiscal balances. Governments have not been entirely myopic therefore. Instead they have been able to exploit an interesting trade-off between tax smoothing and debt management, implying that the more expensive is the use of debt, the more you would try to accommodate tax cuts or encourage tax changes. Conversely, when smoothing taxes is costly, governments tend to rely on debt.

Governments have therefore actively encouraged, or more often accommodated, loose tax policies that deviate from their target paths from time to time, because they have benefited from weak penalties on the use of debt (and hence tax smoothing) for fiscal management. The trade-off between the use of taxes and debt financing strengthens after 1994, with a preference for using debt financing and avoid changes in taxation. Hence, preferences are mostly for tax aversion or tax smoothing, but only weakly accommodating for debt. This pattern has gradually weakened over time since the 1980s, especially pre-crisis (1990-2008), but becomes more tax averse and debt permissive in the crisis period. The last time fiscal discipline was seen in a conventional sense was before 1990, when governments were debt averse but were prepared to raise taxes for their spending or consolidation plans.

Finally, it appears that low debt countries had traditionally allowed debt to fund their fiscal policies pre-crisis or in the crisis, but had run disciplined or tax smoothing policies before then. That is the opposite of conventional wisdom, but their superior debt position allowed them to do so. By contrast, the high debt countries have used taxes to fund their spending activities, but run a slightly more disciplined regime of debt control. 
Open Access This article is distributed under the terms of the Creative Commons Attribution 4.0 International License (http://creativecommons.org/licenses/by/4.0/), which permits unrestricted use, distribution, and reproduction in any medium, provided you give appropriate credit to the original author(s) and the source, provide a link to the Creative Commons license, and indicate if changes were made.

\section{Appendix: Estimation Results}

Table 7 Estimates of Eq. 24 for all countries

\begin{tabular}{lllllll}
\hline & $1960-2011$ & $1960-1989$ & $1960-2008$ & $1990-2008$ & $1994-2008$ & $1994-2011$ \\
\hline$T_{t-1}$ & $0.91^{* * *}$ & $0.90^{* * *}$ & $0.91^{* * *}$ & $0.74^{* * *}$ & $0.69^{* * *}$ & $0.72^{* * *}$ \\
& $(0.02)$ & $(0.03)$ & $(0.02)$ & $(0.13)$ & $(0.08)$ & $(0.08)$ \\
$B_{t-1}$ & -0.00 & -0.01 & -0.00 & 0.01 & $0.02^{* *}$ & $0.01^{* *}$ \\
& $(0.00)$ & $(0.01)$ & $(0.00)$ & $(0.01)$ & $(0.01)$ & $(0.00)$ \\
$r_{t-1}$ & $0.50^{* * *}$ & $0.56^{* * *}$ & $0.51^{* * *}$ & $0.46^{* * *}$ & $0.42^{* * *}$ & $0.47^{* * *}$ \\
& $(0.05)$ & $(0.10)$ & $(0.05)$ & $(0.04)$ & $(0.06)$ & $(0.06)$ \\
$\rho_{t-1}$ & $-0.34^{* * *}$ & $-0.29^{* * *}$ & $-0.33^{* * *}$ & $-0.45^{* * *}$ & $-0.38^{* * *}$ & $-0.37^{* * *}$ \\
& $(0.03)$ & $(0.03)$ & $(0.03)$ & $(0.04)$ & $(0.04)$ & $(0.04)$ \\
Constant & $3.44^{* * *}$ & $3.82^{* * *}$ & $3.40^{* * *}$ & $10.45^{*}$ & $12.39^{* * *}$ & $11.05^{* * *}$ \\
& $(0.63)$ & $(1.11)$ & $(0.65)$ & $(5.14)$ & $(3.27)$ & $(3.42)$ \\
Observations & 1121 & 637 & 1055 & 418 & 330 & 396 \\
Groups & 22 & 22 & 22 & 22 & 22 & 22 \\
$R^{2}$ & 0.95 & 0.93 & 0.95 & 0.68 & 0.66 & 0.66 \\
\hline
\end{tabular}

Standard errors in parentheses

* $(p<0.10),{ }^{* *}(p<0.05),{ }^{* * *}(p<0.01)$

Table 8 Estimates of Eq. 24 for low debt countries

\begin{tabular}{lllllll}
\hline & $1960-2011$ & $1960-1989$ & $1960-2008$ & $1990-2008$ & $1994-2008$ & $1994-2011$ \\
\hline$T_{t-1}$ & $0.90^{* * *}$ & $0.90^{* * *}$ & $0.91^{* * *}$ & $0.69^{* * *}$ & $0.63^{* * *}$ & $0.66^{* * *}$ \\
& $(0.02)$ & $(0.03)$ & $(0.02)$ & $(0.16)$ & $(0.12)$ & $(0.11)$ \\
{$[1 \mathrm{ex}] B_{t-1}$} & 0.00 & -0.01 & 0.00 & $0.03^{* *}$ & $0.03^{* *}$ & 0.01 \\
& $(0.01)$ & $(0.01)$ & $(0.01)$ & $(0.01)$ & $(0.01)$ & $(0.01)$ \\
{$[1 \mathrm{ex}] r_{t-1}$} & $0.55^{* * *}$ & $0.59^{* * *}$ & $0.53^{* * *}$ & $0.35^{* * *}$ & $0.39^{* * *}$ & $0.61^{* * *}$ \\
& $(0.10)$ & $(0.12)$ & $(0.10)$ & $(0.11)$ & $(0.09)$ & $(0.13)$ \\
{$[1 \mathrm{ex}] \rho_{t-1}$} & $-0.40^{* * *}$ & $-0.32^{* * *}$ & $-0.39^{* * *}$ & $-0.56^{* * *}$ & $-0.43^{* * *}$ & $-0.42^{* * *}$ \\
& $(0.05)$ & $(0.05)$ & $(0.06)$ & $(0.08)$ & $(0.05)$ & $(0.04)$ \\
{$[1 \mathrm{ex}]$ Constant } & $3.88^{* * *}$ & $3.94^{* * *}$ & $3.83^{* * *}$ & $13.05^{*}$ & $15.30^{* *}$ & $14.13^{* * *}$ \\
& $(0.83)$ & $(1.29)$ & $(0.86)$ & $(6.80)$ & $(5.31)$ & $(4.87)$ \\
Observations & 662 & 376 & 623 & 247 & 195 & 234 \\
Groups & 13 & 13 & 13 & 13 & 13 & 13 \\
$R^{2}$ & 0.95 & 0.93 & 0.95 & 0.64 & 0.60 & 0.62 \\
\hline
\end{tabular}

Standard errors in parentheses

* $(p<0.10),{ }^{* *}(p<0.05),{ }^{* * *}(p<0.01)$ 
Table 9 Estimates of Eq. 24 for high debt countries

\begin{tabular}{lllllll}
\hline & $1960-2011$ & $1960-1989$ & $1960-2008$ & $1990-2008$ & $1994-2008$ & $1994-2011$ \\
\hline$T_{t-1}$ & $0.90^{* * *}$ & $0.85^{* * *}$ & $0.89^{* * *}$ & $0.81^{* * *}$ & $0.74^{* * *}$ & $0.77^{* * *}$ \\
& $(0.03)$ & $(0.06)$ & $(0.03)$ & $(0.04)$ & $(0.05)$ & $(0.07)$ \\
$B_{t-1}$ & 0.00 & -0.01 & 0.00 & 0.01 & $0.01^{* *}$ & $0.01^{* *}$ \\
& $(0.00)$ & $(0.01)$ & $(0.00)$ & $(0.01)$ & $(0.00)$ & $(0.00)$ \\
$r_{t-1}$ & $0.50^{* * *}$ & $0.63^{* * *}$ & $0.53^{* * *}$ & $0.48^{* * *}$ & $0.42^{* * *}$ & $0.43^{* * *}$ \\
& $(0.05)$ & $(0.13)$ & $(0.05)$ & $(0.06)$ & $(0.07)$ & $(0.07)$ \\
$\rho_{t-1}$ & $-0.30^{* * *}$ & $-0.27^{* * *}$ & $-0.28^{* * *}$ & $-0.34^{* * *}$ & $-0.34^{* * *}$ & $-0.35^{* * *}$ \\
& $(0.03)$ & $(0.03)$ & $(0.03)$ & $(0.05)$ & $(0.05)$ & $(0.04)$ \\
Constant & $3.24^{* * *}$ & $4.67^{* * *}$ & $3.33^{* * *}$ & $6.60^{* * *}$ & $9.34^{* * *}$ & $8.22^{* * *}$ \\
& $(0.69)$ & $(1.43)$ & $(0.73)$ & $(1.33)$ & $(1.70)$ & $(2.52)$ \\
Observations & 459 & 261 & 432 & 171 & 135 & 162 \\
Groups & 9 & 9 & 9 & 9 & 9 & 9 \\
$R^{2}$ & 0.96 & 0.93 & 0.96 & 0.83 & 0.76 & 0.74 \\
\hline
\end{tabular}

Standard errors in parentheses

${ }^{*}(p<0.10),{ }^{* *}(p<0.05),{ }^{* * *}(p<0.01)$

\section{References}

Agell J (1996) Why Sweden's welfare state needed reform. Econ J 106(439):1760-1771

Agell J, Englund P, Södersten J (1996) Tax reform of the century-the Swedish experiment. Nat Tax J 49(4):643-664

Barro RJ (1979) On the determination of the public debt. J Polit Econ 87(5):940-971

Bohn H (1990) Tax smoothing with financial instruments. Am Econ Rev 80(5):1217-1230

Cerniglia F, Dia E, Hughes Hallett A (2016) Debt stability under entitlement spending. University of Milan Bicocca Department of Economics, Management and Statistics Working Paper (351)

Checherita C, Hughes Hallett AJ, Rother P (2014) Fiscal sustainability using growth-maximising debt targets. Appl Econ 46(6):638-647

Chudik A, Pesaran MH (2013) Large panel data models with cross-sectional dependence: a survey CESifo Working Paper 4371. CESifo Institute, Munich

Coricelli F, Fiorito R (2013) Myths and facts about fiscal discretion: a new measure of discretionary expenditure. Documents de travail du Centre d'Economie de la Sorbonne (13033)

Fisher PG, Hughes Hallett AJ (1988) Efficient solution techniques for linear and non-linear rational expectations models. J Econ Dyn Control 12(4):635-657

Ghosh AR, Kim JI, Mendoza EG, Ostry JD, Qureshi MS (2013) Fiscal fatigue, fiscal space and debt sustainability in advanced economies. Econ J 123(566):F4-F30

Leeper EM, Walker TB (2011) Fiscal limits in advanced economies. Economic Papers: a journal of applied economics and policy 30(1):33-47

Malinvaud E (1970) Statistical methods in econometrics. North Holland, Amsterdam

Mauro P, Romeu R, Binder A, Zaman A (2015) A modern history of fiscal prudence and profligacy. J Monet Econ 76:55-70

Prota F, Grisorio MJ (2018) Public expenditure in time of crisis: are Italian policymakers choosing the right mix? Econ Polit 35(2):337-365. https://doi.org/10.1007/s40888-018-0124-4

White JS (1961) Asymptotic expansions for the mean and variance of the serial correlation coefficient. Biometrika 48(1-2):85-94 